\title{
Evaluation of Diets with Inclusion of Hydrothermal, Phytase, and Organic Acid Pretreated Canola Meal on Nutrient Digestibility in Swine
}

\author{
Enkhjargal Darambazar ${ }^{1}$, Daalkhaijav Damiran ${ }^{1} \&$ Denise Beaulieu ${ }^{1}$ \\ ${ }^{1}$ Department of Animal and Poultry Science, University of Saskatchewan, 51 Campus Drive, Saskatoon, SK S7N \\ 5A8, Canada
}

Correspondence: Enkhjargal Darambazar, Department of Animal and Poultry Science, University of Saskatchewan, 51 Campus Drive, Saskatoon, SK S7N 5A8, Canada. Tel: 306-966-2155. E-mail: end172@usask.ca

Received: December 30, 2019 Accepted: February 1, 2020 Online Published: February 8, 2020

doi:10.5539/sar.v9n2p41

URL: https://doi.org/10.5539/sar.v9n2p41

\begin{abstract}
The objective of this study was to evaluate the effects of dietary inclusion of hydrothermal, phytase, and organic acid pretreated canola meal (CM) on nutrient digestibility in swine. A basal diet barley, wheat, and CM based, was formulated. Four diets containing $30 \%$ hydrothermal pretreated $\mathrm{CM}$ with $50 \%$ moisture and $40^{\circ} \mathrm{C}$, phytase (1000 FTU/kg activity), and either citric acid (CA), malic acid (MA), or lactic acid (LA), and a control containing pretreated $\mathrm{CM}$ without phytase or organic acid were fed to 12 ileal-cannulated finisher pigs (initial average BW $105.3 \pm 2.7 \mathrm{~kg}$ ) in a completely randomized design over two periods of 9 days per period. Nutrient composition and phytate content of the diets, ileal digesta, and feces were analyzed and apparent ileal and total tract digestibilities were determined. The inclusion of hydrothermal, phytase, and CA or MA pretreated CM in the diet decreased phytate $\mathrm{P}$ (by up to $38.6 \%$ ) $(p<0.05$ ), consequently increasing available $\mathrm{P}$ (by up to $55.6 \%$ ). Apparent ileal digestibility (AID) was improved for P by $19.9-35.1 \%$ units and apparent total tract digestibility of DM by $10.3-14.8 \%$ units, of protein by $6.6-12.1 \%$ units, and of gross energy by $12-17 \%$ units across the treatments $(p<0.05)$, while AID of CP for MA treatment was up by $4.7 \%$ units $(p<0.05)$ relative to the control, indicating improved diet utilization, thus reduced excretion to the environment.
\end{abstract}

Keywords: canola meal, enzyme additive, ileal digestibility, phytate, pig

\section{Introduction}

Poor digestive utilization of phytin-bound phosphorus (P) in canola meal (CM) by nonruminant animals and its consequences on digestibility of nutrients, environment, and diet cost have led to extensive research efforts directed toward understanding its digestion (Jagger, Wiseman, Cole, \& Craigon, 1992; Newkirk \& Classen, 2001; Sauvant, Perez, \& Tran, 2004; Thacker \& Newkirk, 2005; Sands, Ragland, Dilger, \& Adeola, 2009). Phytic acid (PA) binds divalent cations and thus reduces mineral digestibility (Bedford, 2000) and availability in pigs (Maenz, 2001).

Addition of microbial phytase (MP) to diet improved phytate $\mathrm{P}$ [or phytic acid P (PAP)] utilization, increased the total tract digestibility of $\mathrm{P}$ and decreased the excretion of $\mathrm{P}$ from pigs (Beers \& Jongbloed, 1992; Newkirk \& Classen, 2001; Omogbenigun, Nyachoti, \& Slominski, 2003; Beaulieu, Bedford, \& Patience, 2007; Columbus, Niven, Zhu, \& de Lange, 2010; Kerr, Weber, Miller, \& Southern, 2010; Nourmohammadi \& Afzali, 2013; Casas \& Stein, 2015; Dersjant-Li \& Dusel, 2019), therefore it is quite widely used for the livestock industry. Although, there has been inconsistent response of exogenous enzymes in the pig thus far, and the reasons suggested may be due to differences between the species in terms of gastrointestinal physiology (Patience, Bedford, Classen, \& Inborr, 1992; Kemme, Schlemmer, Mroz, \& Jongbloed, 2006) and feed retention time in the stomach (Schlemmer, Jany, Berk, Schulz, \& Rechkemmer, 2001).

Studies have, also, demonstrated increased amino acid (AA) digestibility for broiler chickens (Jia et al., 2012) and nutrients and energy for beef cattle fed a diet containing CM (Damiran, Lardner, Jefferson, Larson, \& McKinnon, 2016; Damiran \& McKinnon, 2018). Moreover, researchers found efficacy of $2.8 \%$ of lactic acid (LA) in reducing Salmonella fecal contamination in pigs (Jørgensen, Kjærsgaard, Wachamann, Jensen, \& 
Knudsen, 2001) and of $2 \%$ of malic acid (MA) in reducing Listeria in poultry (González-Fandos \& Herrera, 2013). Apart from their antimicrobial activity, organic acids (OA) and prebiotics as feed additives demonstrated a positive effect on nutrients digestibilities in swine (Mroz et al., 2000), on bone strength in chickens (Świątkiewicz, Koreleski, \& Arczewska, 2010), and CA and MP independently exhibited a positive impact on morphometry of the small intestine, facilitating nutrient absorption and reducing the metabolic demands of the intestinal tract in broiler chickens (Nourmohammadi \& Afzali, 2013). Supplementation of fumaric acid to starter diets for weaned pigs increased ileal digestibilities of gross energy (GE), crude protein (CP), and AAs (Blank, Mosenthin, Sauer, \& Huang, 1999) and a diet containing 6\% citrate improved PAP utilization in chicks, but it had smaller effect in pigs (Boling, Webel, Mavromichalis, Parsons, \& Baker, 2000). In contrast, others documented that $0.2 \%$ of CA reduced the P-releasing efficacy of phytase in young pigs or chickens (Brenes et al., 2003).

Although to a lesser extent, effects of a combined use of MP and OA were reported as well; a synergistic effect between MP and lactic or formic acid on total P digestibility in growing pigs (Jongbloed, Mroz, van der Weij-Jongbloed, \& Kemme, 2000), improved P digestion and utilization with addition of MP and OAs for starter pigs (Omogbenigun et al., 2003), and addition of 3\% CA and MP to the diet improved ileal nutrients digestibility, growth performance, and increased minerals retention of broiler chickens (Nourmohammadi, Hosseini, Farhangfar, \& Bashtani, 2012).

Still, the effects of processing, phytase, and OAs on diets and nutrients digestibility for monogastrics have been less explored with limited and inconsistent information constraining the applications. Clearly, there is need to investigate changing feed ingredients used in feeds, how animal responds to specific feed and how this can be used to increase the benefit from processing technology, phytase, and prebiotics. The objective of this study was to investigate the effects of dietary inclusion of hydrothermal, phytase, and OA pretreated CM in the ration for swine on diet digestibility.

\section{Materials and Methods}

\subsection{Chemicals and Enzymes}

Analytical grade reagents were purchased from Sigma-Aldrich Canada (Oakville, ON) and Fisher Scientific Canada (Ottawa, ON); hydrochloric acid $(\mathrm{HCl}, 1 \mathrm{M})$, powdered citric and malic acids of $100 \%$ purity, and lactic acid in liquid form of $80 \%$ purity were used for the experiments. The phytase used for the experiments was Quantum Blue 5G (declared potency of $5000 \mathrm{FTU} / \mathrm{g}$; Quantum ${ }^{\circledR}$ Blue; EC 3.1.3.26; AB Vista, Wiltshire, UK). This E. coli-derived 6-phytase initiates dephosphorylation from position 6 on the myo-inositol ring. It was developed specifically for use in swine and poultry feeds, and belongs to the class of histidine acid phytases (Greiner \& Bedford, 2010), is thermostable (maximum recommended temperature is $90.5^{\circ} \mathrm{C}$ ) and water soluble, its optimal $\mathrm{pH}$ is $4.5-5.0(100 \mathrm{~g} / \mathrm{L})$, and it was supplemented according to the activity determined at standard conditions ( $\mathrm{pH} 5.5,37^{\circ} \mathrm{C}, 5 \mathrm{mmol} / \mathrm{L}$ sodium phytate) (ABVista Feed Ingredients, ABVista, Inc.).

\subsection{Experimental Diets and Sample Preparation}

Solvent extracted canola meal (SECM) and two sources of grain (wheat and barley) as feed ingredients were purchased in western Canada. Canola meal was pretreated in a pilot scale mixer (to $200 \mathrm{~kg}$ mixing capacity) and four experimental total mixed diets (TMD) were produced at the Canadian Feed Research Centre (CFRC), North Battleford, Saskatchewan, Canada. Descriptions of CM pretreatment and experimental diets are presented in Table 1.

Table 1. Treatment description of the experimental diets

\begin{tabular}{|c|c|c|c|c|c|c|}
\hline \multirow[t]{2}{*}{ Treatment } & \multirow{2}{*}{$\begin{array}{l}\text { Inclusion rate } \\
\text { of } \mathrm{CM}^{1} \text { in } \\
\text { basal diet }(\%)\end{array}$} & \multicolumn{5}{|c|}{ Pretreatments of CM } \\
\hline & & Phytase source $^{2}$ & Organic acid ${ }^{3}$ & Moisture (\%) & Temperature $\left({ }^{\circ} \mathrm{C}\right)$ & $\mathrm{pH}$ \\
\hline Control & 30 & none & none & 50 & 40 & 5.8 \\
\hline $\mathrm{CA}^{4}$ & 30 & Quantum Blue & Citric acid & 50 & 40 & 4.0 \\
\hline MA & 30 & Quantum Blue & Malic acid & 50 & 40 & 4.0 \\
\hline LA & 30 & Quantum Blue & Lactic acid & 50 & 40 & 4.0 \\
\hline
\end{tabular}

Note. ${ }^{1} \mathrm{CM}$, Solvent extracted canola meal; ${ }^{2}$ Phytase was added at a rate of $0.2 \mathrm{~g} / \mathrm{kg}$ to provide $1000 \mathrm{FTU} / \mathrm{kg}$ activity; ${ }^{3}$ Organic acid was added at a rate of $40 \mathrm{~g} / \mathrm{kg} ;{ }^{4} \mathrm{CA}$, Citric acid; MA, Malic acid; LA, Lactic acid. 
Based on the results of our previous study (Darambazar, Damiran, \& Beaulieu, 2019), 50\% moisture was applied as hot water $\left(\sim 50^{\circ} \mathrm{C}\right)$ to all treatments. This allowed the temperature in the mixer to be maintained at about $40^{\circ} \mathrm{C}$. The control was SECM with moisture addition but without phytase or acid. Pretreatments of CM involved the following: moisture was added to $\mathrm{CM}$ and mixed for $15 \mathrm{~min}$, then $\mathrm{pH}$ was adjusted to $\mathrm{pH} 4$ using either citric, malic, or lactic acid for the treatments CA, MA, or LA, respectively, and mixed for 15 min. Phytase was added at a rate of $0.02 \%$ (to provide $1000 \mathrm{FTU} / \mathrm{kg}$ activity) and continued mixing for an additional $30 \mathrm{~min}$. For the control, $\mathrm{CM}$ was treated with the same moisture addition and processing time as the treatments, but without phytase or acid addition. The pretreated mixture of $\mathrm{CM}$ was dried to approximately $20 \%$ moisture, added to a barley-wheat based basal diet (Table 2) at a 30\% inclusion rate, and processed to make pellets of the TMD for the experimental diets. Ingredient composition formulated for the basal diet is shown in Table 2.

Table 2. Ingredient composition of the basal diet

\begin{tabular}{ll}
\hline Ingredient & Formulated composition $(\%$ as fed) \\
\hline Barley grain & 37.88 \\
Solvent Extracted Canola Meal & 30.00 \\
Wheat soft red winter grain & 25.00 \\
Canola oil & 5.00 \\
Limestone & 0.90 \\
Salt (Sodium Chloride) & 0.48 \\
Celite & 0.40 \\
Swine Vit Premix & 0.10 \\
Titanium Dioxide & 0.10 \\
Swine Trace Mineral Premix & 0.07 \\
Choline Chloride 60\% & 0.07 \\
\hline
\end{tabular}

Diets were formulated to meet or exceed the nutritional requirements recommended by the NRC (2012) to supply approximately $19 \% \mathrm{CP}$ for grower/finisher swine using an identical ingredient profile so that the only difference in the treatments was organic acid. Samples of control and treatment CM and TMD were taken after drying and pelleting, respectively. Canola meal and diet samples were dried in a forced air oven at $55^{\circ} \mathrm{C}$ for $48 \mathrm{~h}$ and ground using Retsch ZM200 grinder (Retsch, Haan, Germany) through 0.5 and $1 \mathrm{~mm}$ screens.

\subsection{Animal Selection and Care}

Twelve crossbred, cannulated pigs (Camborough Plus females x C337 sires, PIC Canada LTD., Winnipeg, MB) weighing an average $104.2 \pm 2.7 \mathrm{~kg}$ were selected on the basis of body weight (BW) and condition. The pigs were housed and managed according to the Canadian Council on Animal Care (2009) guidelines at the Prairie Swine Centre Inc. (PSCI) Saskatoon, Saskatchewan, Canada, utilizing 12 individual metabolism crates. The pigs were surgically fitted with T-cannulas at the terminal end of the ileum when they were approximately 25 to $30 \mathrm{~kg}$ BW. Pens had a plastic-coated, metal floor, polyvinyl chloride walls $(0.85 \mathrm{~m}$ height $)$ fitted with plexiglass windows $(0.3 \times 0.3 \mathrm{~m})$, a single-space dry feeder, and a nipple drinker. Pigs were fed twice daily at 0800 and $1430 \mathrm{~h}$ in 2 equal-weight meals as pellets with one of the four experimental diets, adjusted to an individual pig's BW and had free access to water throughout the experiment. The daily feed allowance was set at $2.8 \times$ the estimated maintenance requirement for energy ( $3200 \mathrm{kcal}$ of $\mathrm{ME} / \mathrm{kg}$ of $\mathrm{BW}^{0.75}$; NRC, 2012) to avoid orts. Feed consumption was observed by feed refusal every day, after each feeding event. Feed refusal amount in the trial was averaged $<150 \mathrm{~g}$ daily and considered negligible.

\subsection{Experimental Design}

Pigs were randomly assigned to one of four dietary treatments in a completely randomized design (CRD). The experiment was conducted in two 9-d periods, each consisting of a 5-d diet acclimation, followed by 2-d collection of ileal digesta and 2-d collection of feces. Individual pig's BW was recorded at the start and end of the trial, and at the start of the second period of the trial. Final BW averaged $121.7 \pm 2.7 \mathrm{~kg}$.

\subsection{Digesta and Excreta Collection and Digestibility Estimation}

Digesta and feces of the pigs were collected during each period to evaluate digestibility of diets. Digesta was collected for $10 \mathrm{~h}$ on each of 2 consecutive days in a polyethylene bag (of $2.3 \mathrm{~kg}$. capacity) attached to the open cannula barrel with 5\% formic acid for preservation. Bags were removed and replaced every 30 to 60 min. Digesta of each individual animal was composited into a collection vessel (a plastic jar of $4 \mathrm{~L}$ capacity), and stored frozen at $-20^{\circ} \mathrm{C}$ during the collection. For fecal collection, a polyethylene bag (of $4.5 \mathrm{~kg}$ capacity) with $5 \%$ 
formic acid for preservation was attached to a ring system glued to the skin around the anus of the animal (Van Kleef, Deuring, \& Van Leeuwen, 1994). Feces were collected continuously with bags replaced a minimum of 2 times per day at 0900 and $1500 \mathrm{~h}$, were pooled by individual pig for each period, and frozen at $-20^{\circ} \mathrm{C}$. The frozen sample was allowed to thaw before processing for freeze drying. Once thawed, the sample was blended in a Waring blender to mix, and subsampled to obtain a representative sample per animal. Digesta and excreta samples were freeze dried using a FreeZone Stoppering Tray Dryer (Models 79480 Series, Labconco Corp. Kansas City, MO, USA). Samples were ground to pass through a $1 \mathrm{~mm}$ or a $0.5 \mathrm{~mm}$ screen for laboratory analysis using a grinder Ultra Centrifugal Mill Type ZM 200 Retsch (Retsch, Haan, Germany). The ileal and fecal apparent digestibilities (AD) of the nutrients were estimated for each pig based on the correction of the titanium dioxide $\left(\mathrm{TiO}_{2}\right)$ content, using the following equation (Jha, Rossnagel, Pieper, Van Kessel, \& Leterme, 2010):

$$
A D(\%)=\left\{1-\left[\left(I A_{d} / I A_{f, i}\right) /\left(N_{d} / N_{f, i}\right)\right]\right\} \times 100
$$

Where, $I A_{d}$ and $I A_{f, i}$ are the $\mathrm{TiO}_{2}$ contents in the diets and feces/ilealdigesta, respectively, and $N_{d}$ and $N_{f, i}$ are the nutrient contents in the diets and feces/ileal digesta, respectively. For all calculations, analyzed values of $\mathrm{TiO}_{2}$ and AAs for each diet, ileal digesta, and feces were used.

\subsection{Chemical Analysis}

Amino acids were analyzed at Cumberland Valley Analytical Services, Hagerstown, MD, USA on reverse phase HPLC. Dry matter (DM) of the feed and freeze-dried digesta and feces was determined by drying at $135^{\circ} \mathrm{C}$ in a forced air oven for 2 hours (Method 930.15; AOAC, 2000). Crude protein (CP) was determined by the combustion method using a LECO FP-528 total nitrogen analyzer (St. Joseph, MI, USA) and CP was then calculated as $\mathrm{N} \times 6.25$ (Method 968.06, AOAC, 2000). Total P was analyzed colorimetrically with vanadatemolybdate reagent (Method 946.06, AOAC, 2000) and ash content was measured after burning at $550^{\circ} \mathrm{C}$ for a minimum of 16 hours or overnight (method 942.05; AOAC, 2000). Available P content was estimated as the difference between the values of total P and PAP. Titanium dioxide was determined as described in Darambazar (2019), if briefly, by digesting samples for 2 hours at $420^{\circ} \mathrm{C}$ (Kjeldahl digestion block, Foss Tecator Digestor Auto) in concentrated sulfuric acid $\left(\mathrm{H}_{2} \mathrm{SO}_{4}\right.$, reagent grade, 95-98\%), adding hydrogen peroxide $\left(\mathrm{H}_{2} \mathrm{O}_{2}\right.$, reagent grade, $30 \%$ ) and measuring absorbance at $410 \mathrm{~nm}$ on a spectrophotometer (Ultrospec III UV/Visible Spectrophotometer, Pharmacia Model 80-2097-62 LKB Biochrom, England). Standards were prepared by spiking blanks with increasing amounts of $\mathrm{TiO}_{2}$, resulting in a linear calibration curve (Myers, Ludden, Nayigihugu, \& Hess, 2004). Gross energy (GE) was determined using a 6400 Automatic isoperibol system bomb calorimeter (Parr Instrument Company, Moline, Illinois, USA, 2010). All analyses were performed in duplicates.

\subsubsection{Phytate Determination}

Phytate determination was carried out using a modified colorimetric method as described in Darambazar (2018) and Darambazar et al. (2019). Briefly, the sample was extracted in $10 \mathrm{~mL}, 0.64 \mathrm{~N}$ hydrochloric acid $(\mathrm{HCl})$ on a platform shaker (VWR Advanced Digital Shaker Model 3750) for $16 \mathrm{~h}$, centrifuged at $3000 \mathrm{rpm}$ and $10^{\circ} \mathrm{C}$ for 20 min (Avanti J-E Centrifuge, Beckman-Coulter Mississauga, ON, Canada), and supernatant was added to approximately $1.0 \mathrm{~g}$ sodium chloride $(\mathrm{NaCl}$, reagent grade, $99.99 \%)$ with filtering. Sample was shaken on a shaker for $20 \mathrm{~min}$, allowed to settle at $4^{\circ} \mathrm{C}$ for $60 \mathrm{~min}$, centrifuged at $3000 \mathrm{rpm}$ and $10^{\circ} \mathrm{C}$ for $20 \mathrm{~min}$. One $\mathrm{mL}$ of supernatant was diluted in $24 \mathrm{~mL}$ deionized water. Sodium phytate standard stock solution was prepared out of phytic acid sodium salt hydrate (from rice, $\mathrm{C}_{6} \mathrm{H}_{18} \mathrm{O}_{24} \mathrm{P}_{6} \mathrm{xNa} \mathrm{yH}_{2} \mathrm{O} ; 79 \%$ purity and $20.6 \% \mathrm{P}$; Sigma Aldrich, St. Louis P8810; CAS 14306) and standards of $0,5,10,30,60$, and $80 \mathrm{mg} / \mathrm{mL}$ concentrations were made for calibration curve. Three $\mathrm{mL}$ of sample or standard was combined with $1 \mathrm{~mL}$ of Wade reagent [ferric chloride hexahydrate $\left(\mathrm{FeCl}_{3} \cdot 6 \mathrm{H}_{2} \mathrm{O}\right)$, Fisher Scientific CAS F2877], mixed, and centrifuged at $3000 \mathrm{rpm}$ and $10^{\circ} \mathrm{C}$ for 10 min. Absorbance of color reaction was read at $500 \mathrm{~nm}$ on a spectrophotometer (Ultrospec III UV/Visible Spectrophotometer, Pharmacia Model 80-2097-62 LKB Biochrom, England). The analysis was done in duplicates for each sample.

\subsection{Statistical Analysis}

Digestibility and diet data were analyzed using the Proc Mixed Model procedure of SAS (2016) with treatment included as a fixed effect. Period was treated as repeated measures. Each animal (pig) was considered an experimental unit. Means were determined using the least squares means statement of SAS and were separated using Tukey's multi-treatment comparison method (Saxton, 1998). For all statistical analyses, significance was declared at $p<0.05$. 


\section{Results and Discussion}

Pigs, in the present study, performed with ADG of $0.99 \pm 0.13 \mathrm{~kg}$ and no differences were observed between the treatments $(p>0.05)$ (data not shown), which agreed with the findings that steeping high-moisture corn with phytase (Columbus et al., 2010) or regardless of source or dosing (Langbein et al., 2013), phytase had no effect on ADG, but contradicted with the findings of a post-weaning study by Wilcock (2012) that addition of phytase improved live weight gain ( $0.46 \mathrm{~kg}$ of extra gain at 21 days). The nutrient compositions calculated and analyzed for TMD and CM (untreated), respectively, are presented in Table 3.

The nutrient composition of the untreated CM in the current study was comparable to that reported elsewhere (Newkirk \& Classen, 2002; Thacker \& Newkirk, 2005), identical in CP content, lower in ash, total P, PAP, methionine (Met), leucine (Leu), isoleucine (Ileu), phenylalanine (Phe), lysine (Lys), and arginine (Arg) and higher in available P, valine (Val), and tryptophan (Trp), than the meal derived from black-seeded Brassica napus canola (Slominski, Jia, Rogiewicz, Nyachoti, \& Hickling, 2012), higher in CP, total P, and available P, but lower in moisture, total P, available P, PAP, and ash than the CM studied by others (Tahir et al. 2012; NRC, 2012; Damiran, Lardner, Jefferson, Larson, \& McKinnon, 2016; Adewole, Rogiewicz, Dyck, \& Slominski, 2017). The nutrient composition of the experimental diets is demonstrated in Table 4, and it showed that the diets have met or exceeded the required maintenance levels for pigs in the diet formulation.

Table 3. Nutrient composition and energy value of total mixed diet and canola meal

\begin{tabular}{lll}
\hline Item & TMD $^{1}$ & $\mathrm{CM}^{2}$ \\
\cline { 2 - 3 } & Calculated composition (\% DM) & Analyzed composition (\% DM) \\
\hline Dry Matter & 90.13 & 92.49 \\
ME - Swine $(\mathrm{Mcal} / \mathrm{kg})$ & 3.56 & - \\
GE $($ Mcal/kg) & - & 5.12 \\
Ether Extract & 1.60 & - \\
Crude Protein $(\mathrm{N} \times 6.25)$ & 21.11 & 46.19 \\
Crude Fiber & 5.84 & - \\
Ash & 3.90 & 7.49 \\
Ca:P & 1.00 Ratio & - \\
Calcium & 0.60 & - \\
Phosphorus & 0.60 & 1.32 \\
Phosphorus - Available & 0.22 & 0.58 \\
Phytic acid & - & 2.86 \\
Phytate P & - & 0.74 \\
Sodium & 0.23 & - \\
Salt & 0.54 & - \\
Choline, B4 & 332.84 ppm & - \\
Threonine & 0.73 & 0.80 \\
Cysteine & 0.30 & 0.45 \\
Valine & 0.91 & 1.09 \\
Methionine & 0.31 & 0.44 \\
Methionine + Cysteine & 0.61 & 0.89 \\
Isoleucine & 0.71 & 0.81 \\
Leucine & 1.26 & 1.48 \\
Tyrosine & 0.49 & 0.53 \\
Phenylalanine & 0.81 & 0.90 \\
Phenylalanine + Tyrosine & 1.29 & 1.43 \\
Lysine & 0.90 & 1.13 \\
Histidine & 0.48 & 0.58 \\
Arginine & 1.03 & 1.09 \\
Tryptophan & 0.25 & 0.23 \\
\hline Tot & &
\end{tabular}

Note. ${ }^{1}$ Total mixed diet.

${ }^{2}$ Solvent extracted canola meal. 
Table 4 . The nutrient composition and energy values (\% DM) of the experimental diets

\begin{tabular}{|c|c|c|c|c|c|c|}
\hline \multirow[t]{2}{*}{ Item } & \multicolumn{4}{|c|}{ Treatment $^{1}$} & \multirow[t]{2}{*}{ SEM $^{2}$} & \multirow[t]{2}{*}{$p$-value } \\
\hline & Control & $\mathrm{CA}$ & MA & LA & & \\
\hline DM, \% & $77.60^{\mathrm{a}}$ & $77.40^{\mathrm{a}}$ & $77.13^{\mathrm{a}}$ & $74.63^{b}$ & 0.140 & $<0.01$ \\
\hline $\mathrm{CP}$ & $22.75^{\mathrm{a}}$ & $22.10^{\mathrm{a}}$ & $19.65^{\mathrm{b}}$ & $23.47^{\mathrm{a}}$ & 0.257 & $<0.01$ \\
\hline GE, Mcal $/ \mathrm{kg}$ & $5.32^{\mathrm{a}}$ & $5.35^{\mathrm{b}}$ & $5.24^{\mathrm{c}}$ & $5.45^{\mathrm{d}}$ & 0.004 & $<0.01$ \\
\hline Ash & $5.57^{\mathrm{a}}$ & $6.05^{\mathrm{a}}$ & $5.50^{\mathrm{a}}$ & $6.18^{\mathrm{a}}$ & 0.291 & 0.37 \\
\hline Total P & $0.71^{\mathrm{ab}}$ & $0.69^{\mathrm{b}}$ & $0.65^{\mathrm{c}}$ & $0.73^{\mathrm{a}}$ & 0.004 & $<0.01$ \\
\hline Available P & $0.27^{\mathrm{c}}$ & $0.42^{\mathrm{a}}$ & $0.30^{\mathrm{b}}$ & $0.31^{\mathrm{b}}$ & 0.004 & $<0.01$ \\
\hline PAP & $0.44^{\mathrm{a}}$ & $0.27^{\mathrm{c}}$ & $0.36^{\mathrm{b}}$ & $0.42^{\mathrm{a}}$ & 0.004 & $<0.01$ \\
\hline PA & $1.68^{\mathrm{a}}$ & $1.04^{\mathrm{c}}$ & $1.37^{\mathrm{b}}$ & $1.61^{\mathrm{a}}$ & 0.017 & $<0.01$ \\
\hline Thr & $0.82^{\mathrm{a}}$ & $0.78^{a}$ & $0.64^{\mathrm{b}}$ & $0.80^{\mathrm{a}}$ & 0.013 & $<0.01$ \\
\hline Cys & $0.47^{\mathrm{a}}$ & $0.44^{\mathrm{a}}$ & $0.36^{\mathrm{b}}$ & $0.46^{\mathrm{a}}$ & 0.013 & 0.01 \\
\hline Val & $1.12^{\mathrm{a}}$ & $1.06^{\mathrm{a}}$ & $0.92^{\mathrm{b}}$ & $1.11^{\mathrm{a}}$ & 0.016 & $<0.01$ \\
\hline Met & $0.46^{\mathrm{a}}$ & $0.42^{\mathrm{ab}}$ & $0.36^{\mathrm{b}}$ & $0.44^{\mathrm{a}}$ & 0.014 & 0.02 \\
\hline Met+Cys & $0.93^{\mathrm{a}}$ & $0.86^{\mathrm{ab}}$ & $0.72^{\mathrm{b}}$ & $0.89^{\mathrm{a}}$ & 0.025 & 0.01 \\
\hline Ileu & $0.83^{\mathrm{a}}$ & $0.77^{\mathrm{a}}$ & $0.67^{\mathrm{b}}$ & $0.81^{\mathrm{a}}$ & 0.013 & $<0.01$ \\
\hline Leu & $1.52^{\mathrm{a}}$ & $1.44^{\mathrm{a}}$ & $1.24^{\mathrm{b}}$ & $1.49^{\mathrm{a}}$ & 0.023 & $<0.01$ \\
\hline Tyr & $0.53^{\mathrm{a}}$ & $0.49^{\mathrm{a}}$ & $0.38^{\mathrm{b}}$ & $0.52^{\mathrm{a}}$ & 0.012 & $<0.01$ \\
\hline Phe & $0.92^{\mathrm{a}}$ & $0.88^{a}$ & $0.79^{\mathrm{b}}$ & $0.91^{\mathrm{a}}$ & 0.012 & $<0.01$ \\
\hline Phe+Tyr & $1.45^{\mathrm{a}}$ & $1.37^{\mathrm{a}}$ & $1.17^{\mathrm{b}}$ & $1.43^{\mathrm{a}}$ & 0.018 & $<0.01$ \\
\hline Lys & $1.15^{\mathrm{a}}$ & $1.14^{\mathrm{a}}$ & $1.02^{\mathrm{b}}$ & $1.17^{\mathrm{a}}$ & 0.014 & 0.01 \\
\hline His & $0.59^{\mathrm{a}}$ & $0.57^{\mathrm{a}}$ & $0.48^{\mathrm{b}}$ & $0.59^{\mathrm{a}}$ & 0.004 & $<0.01$ \\
\hline Arg & $1.12^{\mathrm{a}}$ & $1.05^{\mathrm{a}}$ & $0.87^{\mathrm{b}}$ & $1.10^{\mathrm{a}}$ & 0.018 & $<0.01$ \\
\hline Trp & $0.25^{\mathrm{a}}$ & $0.24^{\mathrm{a}}$ & $0.18^{\mathrm{b}}$ & $0.27^{\mathrm{a}}$ & 0.009 & 0.01 \\
\hline
\end{tabular}

Note. ${ }^{1}$ Control: Basal diet, $30 \%$ canola meal, $50 \%$ moisture, no acid or phytase addition; Treatment CA: Basal diet, 30\% canola meal, 50\% moisture, $4 \%$ citric acid, 1000 FTU/kg phytase; Treatment MA: Basal diet, 30\% canola meal, 50\% moisture, 4\% malic acid, 1000 FTU/kg phytase; Treatment LA: Basal diet, 30\% canola meal, $50 \%$ moisture, $4 \%$ lactic acid, $1000 \mathrm{FTU} / \mathrm{kg}$ phytase; $\mathrm{n}=6 /$ treatment.

${ }^{2} \mathrm{SEM}=$ pooled standard of means.

${ }^{\mathrm{a}-\mathrm{c}}$ Means within row without common superscript differ significantly at $p<0.05$.

PA, phytic acid; PAP, phytate P or phytic acid P.

In the present study, the CA diet did not vary in DM and CP $(p>0.05)$, while the LA diet had lower DM and the MA diet contained lower protein and AAs compared to the control $(p<0.05)$. These differences may be related to feed processing inconsistencies. Diet composition was affected by addition of phytase in combination with CA or MA in that these diets contained less PAP (by 18.2 to $38.6 \%$ ) and consequently more P available (by 11.1 to $55.6 \%)(p<0.05)$ than the control. The results of CA treatment were comparable with Esmaeilipour et al. (2013) findings when soaking of a broiler feed in CA improved phytate degradation and increased free orthophosphate content. The highest increase (55.6\%) of available $\mathrm{P}$ achieved in the present study was within the range of 52\% to $64 \%$ of $\mathrm{P}$ retention using phytase in corn/SBM-based diets for pigs (Kornegay, 1999), from $18 \%$ to $56 \%$ in maize and from $52 \%$ to $67 \%$ increased $\mathrm{P}$ availability in triticale, but was lower than from $62 \%$ to $74 \%$ range reported in wheat (Düngelhoef, Rodehutscord, Spiekers, \& Pfeffer, 1994). Although the LA treatment in the current study did not have an effect on PAP $(p>0.05)$, it still provided $14.8 \%$ greater available $\mathrm{P}$ than the control $(p<0.05)$, which could be attributed to its similar high total $\mathrm{P}$ content with the control $(p>0.05)$. The nutrient composition of ileal digesta of the pigs is shown in Table 5.

Digesta of pigs fed the treatment diets contained lower total P (Table 5), PA, and PAP than the control (Figure 1) $(p<0.05)$. Studies found that despite supplementation of exogenous phytase to a corn-soybean meal based diet, the released phytate $\mathrm{P}$ was not absorbed in the small intestine and suggested that bacterial $\mathrm{P}$ incorporation might reduce small intestinal $\mathrm{P}$ absorption in pigs (Seynaeve, Janssen, Hesta, van Nevel, \& Wilde, 2000a, b). 
Table 5. The nutrient composition (\% DM) of ileal digesta of pigs fed with the experimental diets

\begin{tabular}{|c|c|c|c|c|c|c|}
\hline \multirow[t]{2}{*}{ Item } & \multicolumn{4}{|c|}{ Treatment $^{1}$} & \multirow[t]{2}{*}{ SEM $^{2}$} & \multirow[t]{2}{*}{$p$-value } \\
\hline & Control & $\mathrm{CA}$ & MA & LA & & \\
\hline DM, \% & 11.08 & 11.93 & 11.24 & 10.78 & 0.634 & 0.65 \\
\hline $\mathrm{CP}$ & 13.67 & 13.63 & 12.65 & 13.43 & 0.325 & 0.10 \\
\hline Ash & 11.17 & 10.86 & 11.33 & 10.95 & 0.305 & 0.58 \\
\hline Total P & $0.89^{\mathrm{a}}$ & $0.53^{\mathrm{b}}$ & $0.55^{\mathrm{b}}$ & $0.67^{\mathrm{b}}$ & 0.050 & $<0.01$ \\
\hline Available P & 0.33 & 0.29 & 0.29 & 0.36 & 0.043 & 0.58 \\
\hline Thr & 0.48 & 0.46 & 0.45 & 0.46 & 0.020 & 0.89 \\
\hline Cys & 0.24 & 0.22 & 0.22 & 0.23 & 0.012 & 0.67 \\
\hline Val & 0.51 & 0.49 & 0.48 & 0.50 & 0.025 & 0.80 \\
\hline Met & 0.13 & 0.11 & 0.12 & 0.13 & 0.009 & 0.42 \\
\hline Met+Cys & 0.37 & 0.34 & 0.34 & 0.37 & 0.018 & 0.55 \\
\hline Ileu & 0.37 & 0.37 & 0.35 & 0.36 & 0.015 & 0.82 \\
\hline Leu & 0.59 & 0.57 & 0.56 & 0.56 & 0.024 & 0.77 \\
\hline Tyr & 0.22 & 0.21 & 0.21 & 0.23 & 0.012 & 0.64 \\
\hline Phe & 0.35 & 0.35 & 0.33 & 0.33 & 0.014 & 0.63 \\
\hline Phe+Tyr & 0.57 & 0.56 & 0.54 & 0.56 & 0.024 & 0.86 \\
\hline Lys & 0.49 & 0.51 & 0.46 & 0.46 & 0.034 & 0.78 \\
\hline His & 0.19 & 0.17 & 0.17 & 0.20 & 0.014 & 0.35 \\
\hline Arg & 0.29 & 0.29 & 0.28 & 0.29 & 0.014 & 0.94 \\
\hline $\operatorname{Trp}$ & 0.09 & 0.09 & 0.08 & 0.09 & 0.004 & 0.40 \\
\hline
\end{tabular}

Note. ${ }^{1}$ Control: Basal diet, $30 \%$ canola meal, $50 \%$ moisture, no acid or phytase addition; Treatment CA: Basal diet, $30 \%$ canola meal, $50 \%$ moisture, $4 \%$ citric acid, 1000 FTU/kg phytase; Treatment MA: Basal diet, 30\% canola meal, 50\% moisture, 4\% malic acid, 1000 FTU/kg phytase; Treatment LA: Basal diet, 30\% canola meal, $50 \%$ moisture, $4 \%$ lactic acid, $1000 \mathrm{FTU} / \mathrm{kg}$ phytase; $\mathrm{n}=6 /$ treatment.

${ }^{2} \mathrm{SEM}=$ pooled standard of means.

${ }^{\mathrm{a}-\mathrm{b}}$ Means within row without common superscript differ significantly at $p<0.05$.

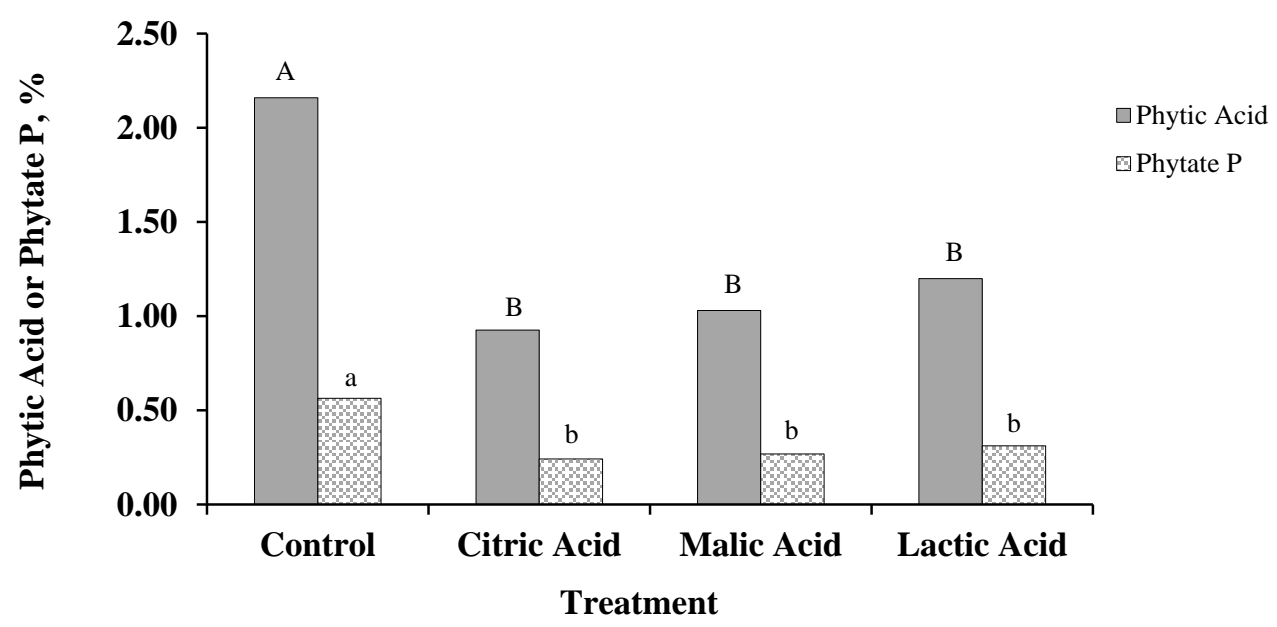

Figure 1. Phytate and phytate P contents (\% DM) of ileal digesta of pigs fed with diets containing $30 \%$ canola meal, with phytase and organic acid addition

Note. Citric Acid = diet containing $30 \%$ canola meal, with phytase and citric acid. Malic Acid = diet containing $30 \%$ canola meal, with phytase and malic acid. Lactic Acid = diet containing 30\% canola meal, with phytase and lactic acid. Control = diet containing $30 \%$ canola meal without phytase or organic acid addition. ${ }^{\mathrm{AB}}$ Bars with different uppercase letters indicate significant difference at $p<0.01 .{ }^{\mathrm{ab}} \mathrm{Bars}$ with different lowercase letters indicate significant difference at $p<0.01$. 
Otherwise, the digesta nutrients (Table 5), AID of DM and CP did not differ between the treatments $(p>0.05)$, except MA treatment for the latter $(p<0.05$ ) (Figure 2), and averaged $92.46 \%$ and $68.95 \%$, respectively (Table 6 and Figure 2), where AID of DM was higher, but AID of CP was lower than those (80.7 and 79.4\%, respectively) obtained by Omogbenigun et al. (2003) in supplementing phytase and OAs to pigs.

Table 6. Apparent ileal digestibility of nutrients (\% DM) of pigs fed with the experimental diets containing hydrothermal, phytase, and organic acid pretreated canola meal

\begin{tabular}{lllllll}
\hline Item & \multicolumn{2}{l}{ Treatment $^{1}$} & & SEM $^{2}$ & $p$-value \\
\cline { 2 - 5 } & Control & CA & MA & LA & & \\
\hline DM & 92.04 & 92.16 & 93.37 & 92.29 & 0.610 & 0.33 \\
Thr & 67.34 & 70.42 & 67.64 & 68.84 & 1.294 & 0.21 \\
Cys & 71.33 & 75.29 & 72.35 & 72.18 & 1.326 & 0.14 \\
Val & 74.66 & 77.44 & 76.12 & 75.51 & 1.100 & 0.25 \\
Met & $85.06^{\text {ab }}$ & $86.61^{\mathrm{a}}$ & $84.90^{\mathrm{ab}}$ & $83.46^{\mathrm{b}}$ & 0.758 & 0.03 \\
Ileu & 74.84 & 76.89 & 75.99 & 75.72 & 0.984 & 0.49 \\
Leu & 78.14 & 80.55 & 79.44 & 79.39 & 0.880 & 0.20 \\
Tyr & 76.74 & 79.33 & 76.07 & 76.07 & 0.936 & 0.06 \\
Phe & 78.38 & 80.78 & 80.97 & 79.82 & 0.917 & 0.17 \\
Lys & 76.16 & 78.42 & 80.11 & 78.16 & 1.087 & 0.11 \\
His & 82.17 & 84.88 & 83.58 & 82.44 & 1.118 & 0.14 \\
Arg & 85.51 & 86.63 & 85.69 & 85.83 & 0.613 & 0.54 \\
Trp & $78.58^{\mathrm{c}}$ & $81.52^{\text {ab }}$ & $78.97^{\text {bc }}$ & $82.51^{\mathrm{a}}$ & 1.005 & $<0.01$ \\
\hline
\end{tabular}

Note. ${ }^{1}$ Control: Basal diet, $30 \%$ canola meal, $50 \%$ moisture, no acid or phytase addition; Treatment CA: Basal diet, 30\% canola meal, 50\% moisture, 4\% citric acid, 1000 FTU/kg phytase; Treatment MA: Basal diet, 30\% canola meal, 50\% moisture, 4\% malic acid, 1000 FTU/kg phytase; Treatment LA: Basal diet, 30\% canola meal, $50 \%$ moisture, $4 \%$ lactic acid, $1000 \mathrm{FTU} / \mathrm{kg}$ phytase; $\mathrm{n}=6 /$ treatment.

${ }^{2} \mathrm{SEM}=$ pooled standard error of means.

${ }^{\mathrm{a}-\mathrm{c}}$ Means within row without common superscript differ significantly at $p<0.05$.

In contrast, the diets had 35.1\%, 31.9\%, and $19.9 \%$ units higher AID of $\mathrm{P}(p<0.05)$ for treatments CA, MA, and LA, respectively, and treatment MA had $4.7 \%$ units higher AID of CP $(p<0.05)$ as compared to the control (Figure 2).

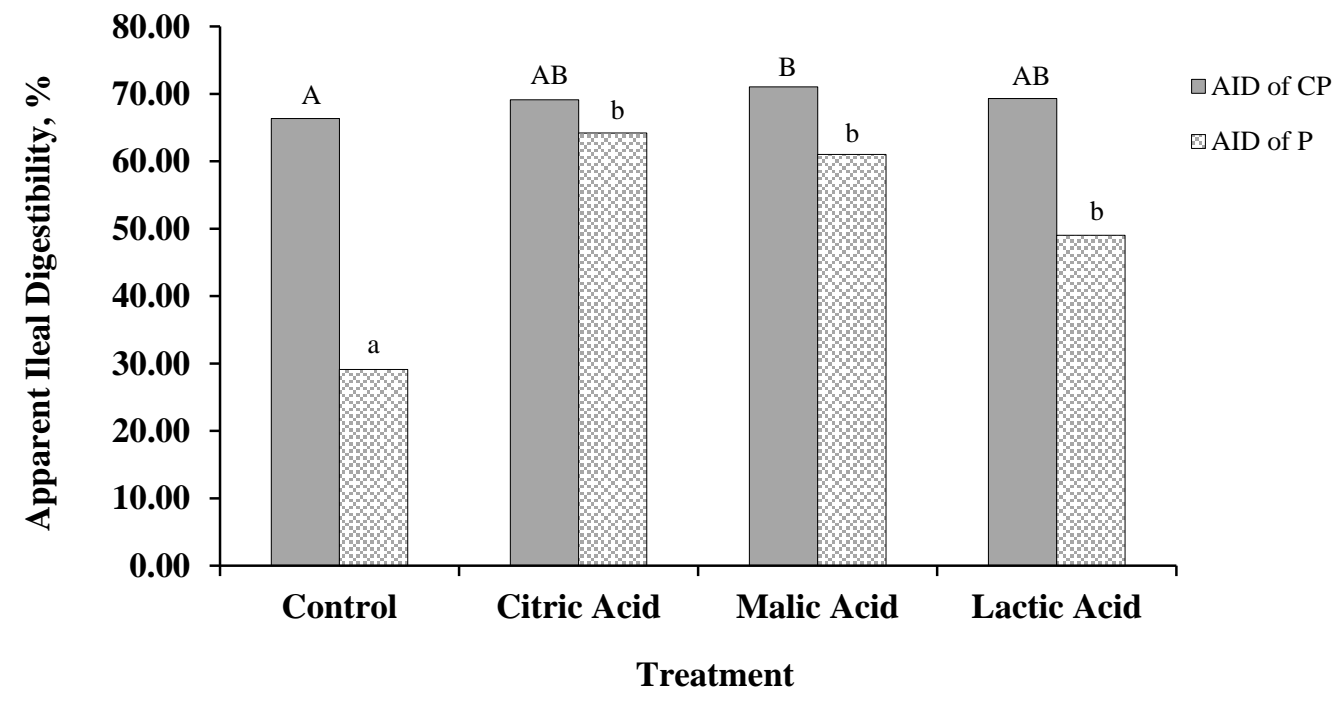

Figure 2. Ileal digestibility of nutrients (\% DM) of pigs fed with diets containing $30 \%$ canola meal with phytase and organic acid addition

Note . Citric Acid = diet containing 30\% canola meal, with phytase and citric acid. Malic Acid = diet containing 
$30 \%$ canola meal, with phytase and malic acid. Lactic Acid = diet containing 30\% canola meal, with phytase and lactic acid. Control $=$ diet containing 30\% canola meal without phytase or organic acid addition. ${ }^{\mathrm{AB}}$ Bars with different uppercase letters indicate significant difference at $p<0.05$. ${ }^{\text {ab }}$ Bars with different lowercase letters indicate significant difference at $p<0.01$.

The improvements of AID of P obtained in the present study were higher than or close to the increase of 21 percentage units reported by Omogbenigun et al. (2003) with addition of MP and OAs to pig diets. Similarly, others have documented greater ATTD of P to $36 \%$ from phytase or CA supplemented diets fed to pigs ( $\mathrm{Li}$, Che, Wang, Hong, \& Thacker, 1998), SBM (Ketaren, Batterham, Dettmann, \& Farrell, 1993), corn-soybean meal (Han, Roneker, Pond, \& Lei, 1998), corn-based diets (Emiola, Akinremi, Slominski, \& Nyachoti, 2009; González-Vega, Walk, \& Stein, 2015), and brown rice (Casas \& Stein, 2015), in broiler chickens (Ptak et al., 2013), and fish (Sajjadi \& Carter, 2004). Possible mechanism of a positive effect of CA in the diet suggested by Han et al. (1998) is that reducing digesta pH results in enhanced solubility of digesta P and increased transit time of digesta (Jongbloed et al., 2000), thereby improving total P absorption.

Apparent ileal digestibility of the nutrients for treatment diets in the present study were higher while the AID of $\mathrm{CP}$ of the control diet was comparable with the AID value of a diet that included $40 \%$ toasted CM (Newkirk \& Classen, 2002). The AID of CP in the current study, however, was lower than that of a swine diet containing SBM (Jagger et al., 1992), wheat, SBM, sorghum diet for broilers (Ravindran et al., 2001), and SBM and rapeseed meal (Dersjant-Li \& Dusel, 2019) with phytase. Feed ingredients with a low CP and AA concentration usually have low AID because the ileal endogenous AA losses $\left(\mathrm{IAA}_{\text {end }}\right)$ contribute relatively more to the ileal output of AA compared with feed ingredients with a moderate or high concentration of CP and AA (Fan, Sauer, Hardin, \& Lien, 1994). Amino acid AIDs did not vary $(p>0.05)$, except Trp was increased $(p<0.05)$ in treatments with CA and LA, by $2.9 \%$ and $3.9 \%$ units, respectively, which was in contrast to the improved digestibility of essential amino acids with $1000 \mathrm{FTU} / \mathrm{kg}$ diet phytase addition, or was $0.6 \%$ lower and $0.4 \%$ higher, respectively than the 3.5\% units improvement of AID of Trp in broiler diet reported by Ravindran et al. (2001). An interaction was observed for Met $(p<0.05)$ in the current study. Results of fecal digestibility of the experimental diets are presented in Table 7.

Table 7. Apparent total tract digestibility of nutrients (\% DM) of pigs fed with the experimental diets

\begin{tabular}{lllllll}
\hline Item & \multicolumn{2}{l}{ Treatment $^{1}$} & & & SEM $^{2}$ & $p$-value \\
\cline { 2 - 5 } & Control & CA & MA & LA & & \\
\hline DM & $68.98^{\mathrm{a}}$ & $81.21^{\mathrm{b}}$ & $79.30^{\mathrm{b}}$ & $83.74^{\mathrm{b}}$ & 1.978 & $<0.01$ \\
CP & $62.82^{\mathrm{a}}$ & $72.37^{\mathrm{bc}}$ & $74.91^{\mathrm{b}}$ & $69.38^{\mathrm{c}}$ & 1.782 & $<0.01$ \\
GE & $51.04^{\mathrm{a}}$ & $64.36^{\mathrm{b}}$ & $68.01^{\mathrm{b}}$ & $63.03^{\mathrm{b}}$ & 2.656 & $<0.01$ \\
\hline
\end{tabular}

Note. ${ }^{1}$ Control: Basal diet, $30 \%$ canola meal, $50 \%$ moisture, no acid or phytase addition; Treatment CA: Basal diet, 30\% CM, 50\% moisture, 4\% citric acid, 1000 FTU/kg phytase; Treatment MA: Basal diet, 30\% canola meal, $50 \%$ moisture, $4 \%$ malic acid, 1000 FTU/kg phytase; Treatment LA: Basal diet, 30\% canola meal, 50\% moisture, $4 \%$ lactic acid, $1000 \mathrm{FTU} / \mathrm{kg}$ phytase; $\mathrm{n}=6 /$ treatment.

${ }^{2} \mathrm{SEM}=$ pooled standard error of means.

${ }^{\mathrm{a}-\mathrm{c}}$ Means within row without common superscript differ significantly at $p<0.05$.

Apparent total tract digestibilities (ATTD) of the treatment diets were increased by $12.2,10.3$, and $14.8 \%$ units for DM, by 9.6, 12.1, and 6.6\% units for CP, and by 13.3, 17, and 12\% units for GE for CA, MA, and LA, respectively $(p<0.05)$. The ATTD values observed in the current study were similar or higher for DM and CP, but lower for GE than those reported for digestibility of rapeseed meal in pigs (Boisen \& Fernandez, 1995) and for pigs fed diets supplemented with 11\% CM (Thacker, 2001). However, ATTD of CP in the present study was much below the fecal apparent digestibility of N of SBM containing diets for swine (Jagger et al., 1992). No effect of phytase supplementation for pigs was found on AID of CP and AA and on ATTD of CP and GE by others (Liao et al., 2005; Beaulieu et al., 2007), which was partially in agreement or in contrast with the results in the present study. Studying different phytase sources, Kerr et al. (2010) have confirmed the inconsistency of the effect of dietary phytase on GE digestibility.

Overall, our findings corresponded in part to that reported elsewhere that phytase and OAs or phytase doses increased AID of P, phytate, and N, ATTD of P, N, Na, energy, ME, and retainable P, and reduced P excretion (Omogbenigun et al., 2003; Kerr et al., 2010; Dersjant-Li \& Dusel, 2019). 


\section{Summary and Conclusions}

Results of the present study have shown that nutrient quality and digestibility of swine diet can be improved with inclusion of hydrothermal, phytase, and organic acid pretreated CM in the diet at a 30\% level. As a result, greater available $\mathrm{P}$ could be achieved for the animals due to higher phytate $\mathrm{P}$ reduction, more evidently for the diets with phytase and citric acid or malic acid. The study, also, revealed that these additives can improve apparent ileal and total tract digestibilities for the major nutrients and energy, increasing AID of P the most $(19.9-35.1 \%$ units), protein (4.7\% units), and Trp (2.9-3.9\% units), and ATTD of DM (10.3-14.8\% units), protein (6.6-12.1\% units), and GE (12-17\% units) across the treatments. Thus, there is a strong potential to reduce the increasing feed cost by utilizing a low-cost co-product as $\mathrm{CM}$ which would benefit animals by providing more available nutrients and reducing $\mathrm{P}$ and $\mathrm{N}$ excretions to the environment. Undoubtedly, further research is necessary to determine the best inclusion level of the feed additives and pretreated feedstuff in the diet of pigs to maximize the effect and cost efficiency, to better understand why specific nutrient respond to a greater extent and how this can be used to increase the benefit from supplementation, which will provide sustainability for the livestock industry.

\section{Acknowledgements}

This study was funded by the SaskCanola Fund (SaskCanola), Alberta Crop Industry Development Fund Ltd. (ACIDF), and Natural Sciences and Engineering Research Council (NSERC). We thank Dr. T. Scott for assisting with funding and experimental design. The authors acknowledge Canadian Feed Research Centre (North Battleford, Saskatchewan) and Prairie Swine Centre Inc. (Saskatoon, Saskatchewan) staff. Our gratitude extends to Khalil Sahtout for helping in the animal trial.

\section{References}

Adeola, O., \& Cowieson, A. J. (2011). Board-invited review: Opportunities and challenges in using exogenous enzymes to improve nonruminant animal production. Journal of Animal Science, 89, 3189-3218. https://doi.org/10.2527/jas.2010-3715

Adewole, D. I., Rogiewicz, A., Dyck, B., \& Slominski, B. A. (2017). Effects of canola meal source on the standardized ileal digestible amino acids and apparent metabolizable energy contents for broiler chickens. Poultry Science, 96(12), 4298-4306. https://doi.org/10.3382/ps/pex245

AOAC (Association of Official Analytical Chemists). (2000). Official methods of analysis (17th ed.), Arlington, VA, USA.

Beaulieu, A. D., Bedford, M. R., \& Patience, J. F. (2007). Supplementing corn or corn-barley diets with an $E$. coli-derived phytase decreases total and soluble $\mathrm{P}$ output by weanling and growing pigs. Canadian Journal of Animal Science, 87, 353-364. https://doi.org/10.4141/CJAS06032

Bedford, M. R. (2000). Exogenous enzymes in monogastric nutrition their current value and future benefits. Animal Feed Science and Technology, 86, 1-13. https://doi.org/10.1016/S0377-8401(00)00155-3

Beers, S., \& Jongbloed, A. W. (1992). Effect of supplementary Aspergillus niger phytase in diets for piglets on their performance and apparent digestibility of phosphorus. Animal Production, 55, 425-430. https://doi.org/10.1017/S0003356100021127

Blank, R., Mosenthin, R., Sauer, W. C., \& Huang, S. (1999). Effect of fumaric acid and dietary buffering capacity on ileal and fecal amino acid digestibilities in early-weaned pigs. Journal of Animal Science, 77, 2974-2984. https://doi.org/10.2527/1999.77112974x

Boisen, S., \& Fernandez, J. A. (1995). Prediction of the apparent ileal digestibility of protein and aminoacids in feedstuffs and feed mixtures for pigs by in vitro analyses. Animal Feed Science and Technology, 51, 29-43. https://doi.org/10.1016/0377-8401(94)00686-4

Boling, S. D., Webel, D. M., Mavromichalis, I., Parsons, C. M., \& Baker, D. H. (2000). The effects of citric acid on phytate-phosphorus utilization in young chicks and pigs. Journal of Animal Science, 78, 682-689. https://doi.org/10.2527/2000.783682x

Brenes, A., Viveros, A., Arija, I., Centeno, C., Pizarro, M., \& Bravo, C. (2003). The effect of citric acid and microbial phytase on mineral utilization in broiler chicks. Animal Feed Science and Technology, 110, 201-219. https://doi.org/10.1016/S0377-8401(03)00207-4

Canadian Council on Animal Care. (2009). CCAC guidelines on: the care and use of farm animals in research, teaching and testing. CCAC, Ottawa, Canada. Retrieved from http://www.ccac.ca/Documents/Standards/Guidelines/Farm_Animals.pdf 
Casas, G. A., \& Stein, H. H. (2015). Effects of microbial phytase on the apparent and standardized total tract digestibility of phosphorus in rice coproducts fed to growing pigs. Journal of Animal Science, 93(7), 3441-3448. https://doi: 10.2527/jas.2015-8877

Columbus, D., Niven, S. J., Zhu, C. L., \& de Lange, C. F. M. (2010). Phosphorus utilization in starter pigs fed high-moisture corn-based liquid diets steeped with phytase. Journal of Animal Science, 88(12), 3964-3976. https://doi.org/10.2527/jas.2010-3011

Damiran, D., \& McKinnon, J. J. (2018). Evaluation of wheat-based dried distillers grains with solubles or canola meal derived from Brassica napus seed as an energy source for feedlot steers. Translational Animal Science, 2, S139-S144. https://doi.org/10.1093/tas/txy051

Damiran, D., Lardner, H. A., Jefferson, P. G., Larson, K., \& McKinnon, J. J. (2016). Effects of supplementing spring calving beef cows grazing barley crop residue with canola meal and wheat-based dry distillers grains with solubles on performance, reproductive efficiency, and system cost. The Professional Animal Scientist, 32, 400-410. https://doi.org/10.15232/pas.2015-01479

Darambazar, E. (2018). Method of phytic acid determination in food, feed, and plant materials. Assay protocol, University of Saskatchewan. pp. 4. https://doi.org/10.13140/RG.2.2.14852.27520

Darambazar, E. (2019). Determination of titanium dioxide as a livestock digestibility marker. Assay protocol. University of Saskatchewan. Saskatchewan, Canada. pp. 10. https://doi.org/10.13140/RG.2.2.14852.27520

Darambazar, E., Damiran, D., \& Beaulieu, D. (2019). Effects of hydrothermal, phytase, and organic acid pretreatments of canola meal on phytate level of the meal. Sustainable Agriculture Research, 8, 35-47. https://doi.org/10.5539/sar.v8n4p35

Dersjant-Li, Y., \& Dusel, G. (2019). Increasing the dosing of a Buttiauxella phytase improves phytate degradation, mineral, energy, and amino acid digestibility in weaned pigs fed a complex diet based on wheat, corn, soybean meal, barley, and rapeseed meal. Journal of Animal Science, 97, 2524-2533. https://doi.org/10.1093/jas/skz151

Düngelhoef, M., Rodehutscord M., Spiekers H., \& Pfeffer, E. (1994). Effects of supplemental microbial phytase on availability of phosphorus contained in maize, wheat and triticale to pigs. Animal Feed Science and Technology, 49, 1-10. https://doi.org/10.1016/0377-8401(94)90076-0

Emiola, A., Akinremi, O., Slominski, B. A., \& Nyachoti, C. M. (2009). Nutrient utilization and manure P excretion in growing pigs fed corn-barley-soybean based diets supplemented with microbial phytase. Animal Science Journal, 80, 19-26, https://doi.org/10.1111/j.1740-0929.2008.00590.x

Esmaeilipour, O., Van Krimpen, M. M., Jongbloed, A. W., De Jonge, L. H., \& Bikker, P. (2013). The effects of temperature, moisture, duration of incubation time, calcium level, and soaking with water or citric acid on in vitro phytate degradation in a wheat-barley-rye-soybean meal-based diet. Animal Feed Science and Technology, 183, 168-174, https://doi.org/10.1016/j.anifeedsci.2013.05.001

Fan, M. Z., Sauer, W. C., Hardin, R. T., \& Lien, K. A. (1994). Determination of apparent ileal amino acid digestibility in pigs: effect of dietary amino acid level. Journal of Animal Science, 72(11), 2851-2859. https://doi.org/10.2527/1994.72112851x

González-Fandos, E., \& Herrera, B. (2013). Efficacy of malic acid against Lysteria monocytogenes attached to poultry skin during refrigerated storage. Poultry Science, 92, 1936-1941. https://doi.org/10.3382/ps.2012-02968

González-Vega, J. C., Walk, C. L., \& Stein, H. H. (2015). Effect of phytate, microbial phytase, fiber, and soybean oil on calculated values for apparent and standardized total tract digestibility of calcium and apparent total tract digestibility of phosphorus in fish meal fed to growing pigs. Journal of Animal Science, 93, 4808-4818. https://doi.org/10.2527/jas.2015-8992

Han, Y. M., Roneker, K. R., Pond, W. G., \& Lei, X. G. (1998). Adding wheat middlings, microbial phytase, and citric acid to corn soybean meal diets for growing pigs may replace inorganic phosphorus supplementation. Journal of Animal Science, 76, 2649-2656. https://doi.org/10.2527/1998.76102649x

Jagger, S., Wiseman, J., Cole, D. J. A., \& Craigon, J. (1992). Evaluation of inert markers for the determination of ileal and faecal apparent digestibility values in the pig. British Journal of Nutrition, 68, 729-739. https://doi.org/10.1079/BJN19920129

Jia, W., Mikulski, D., Rogiewicz, A., Zduńczyk, Z., Jankowski, J., \& Slominski, B. A. (2012). Low-fiber canola. 
Part 2. Nutritive value of the meal. Journal of Agricultural and Food Chemistry, 60, 12231-12237. https://doi.org/10.1021/jf302118c

Jha, R., Rossnagel, B., Pieper, R., Van Kessel, A., \& Leterme, P. (2010). Barley and oat cultivars with diverse carbohydrate composition alter ileal and total tract nutrient digestibility and fermentation metabolites in weaned piglets. Animal, 4(5), 724-731. https://doi.org/10.1017/S1751731109991510

Jongbloed, A. W., Mroz, Z, van der Weij-Jongbloed, R., \& Kemme, P. A. (2000). The effects of microbial phytase, organic acids and their interaction in diets for growing pigs. Livestock Production Science, 67, 113-122. https://doi.org/10.1016/S0301-6226(00)00179-2

Jørgensen, L., Kjærsgaard, H. D., Wachamann, H., Jensen, B. B., \& Knudsen, K. E. B. (2001). Effect of pelleting and use of lactic acid in feed on Salmonella prevalence and productivity in weaners. Proceedings 4th International Symposium on the epidemiology and control of salmonella and other food borne pathogens in pork, Leipzig. pp. 109-111. https://doi.org/10.31274/safepork-180809-207

Kemme, P. A., Schlemmer, U., Mroz, Z., \& Jongbloed, A. W. (2006). Monitoring the stepwise phytate degradation in the upper gastrointestinal tract of pigs. Journal of the Science of Food and Agriculture, 86, 612-622. https://doi.org/10.1002/jsfa.2380

Kerr, B. J., Weber, T. E., Miller, P. S., \& Southern, L. L. (2010). Effect of phytase on apparent total tract digestibility of phosphorus in corn-soybean meal diets fed to finishing pigs. Journal of Animal Science, 88, 238-247. https://doi.org/10.2527/jas.2009-2146

Ketaren, P. P., Batterham, E. S., Belinda Dettmann, E., \& Farrell, D. J. (1993). Phosphorus studies in pigs 3. Effect of phytase supplementation on the digestibility and availability of phosphorus in soya-bean meal for grower pigs. British Journal of Nutrition, 70, 289-311. https://doi.org/10.1079/BJN19930123

Kornegay, E.T. (1999). Application of phytase for retention of nonphosphorus nutrients. Proceedings MD Nutritional Conference, 46, 83-103.

Langbein, K. B., Woodworth, J. C., Goodband, R. D., Tokach, M. D., Nelssen, J. L., Dritz, S. S., \& DeRouchey, J. M. (2013). Effects of superdosing phytase in diets with adequate phosphorus on finishing pig growth performance and carcass characteristics. Kansas Agricultural Experiment Station Research Reports, O(10), 128-131. https://doi.org/10.4148/2378-5977.7044

Li, D. F., Che, X. R., Wang, Y. Q., Hong, C., \& Thacker, P. A. (1998). The effect of microbial phytase, vitamin D3, and citric acid on growth performance and phosphorus, nitrogen, and calcium digestibility in growing swine. Animal and Feed Science Technology, 73, 173-186. https://doi.org/10.1016/S0377-8401(98)00124-2

Liao, S. F., Kies, A. K., Sauer, W. C., Zhang, Y. C., Cervantes, M., \& He, J. M. (2005). Effect of phytase supplementation to a low-and a high-phytate diet for growing pigs on the digestibilities of crude protein, amino acids, and energy. Journal of Animal Science, 83, 2130-2136. https://doi.org/10.2527/2005.8392130x

Maenz, D. D. (2001). Enzymatic characteristics of phytases as they relate to their use in animal feeds. In: Enzymes in Farm Animal Nutrition, M.R. Bedford \& G.G. Partridge, ed. CABI Publishing, New York, NY. pp. 61-84. https://doi.org/10.1079/9780851993935.0061

Mroz, Z., Jongbloed, A. W., Partanen, K. H., Vreman, K., Kemme, P. A., \& Kogut, J. (2000). The effects of calcium benzoate in diets with or without organic acids on dietary buffering capacity, apparent digestibility, retention of nutrients, and manure characteristics in swine. Journal of Animal Science, 78, 2622-2632. https://doi.org/10.2527/2000.78102622x

Myers, W. D., Ludden, P. A., Nayigihugu, V., \& Hess, B. W. (2004). Technical Note: A procedure for the preparation and quantitative analysis of samples for titanium dioxide. Journal of Animal Science, 82, 179-183. https://doi.org/10.2527/2004.821179x

Newkirk, R. W., \& Classen, H. L. (2001). The non-mineral nutritional impact of phytate in canola meal for broiler chicks. Animal and Feed Science Technology, 91, 115-128. https://doi.org/10.1016/S0377-8401(01)00241-3

Newkirk, R. W., \& Classen, H. L. (2002). The effects of toasting canola meal on body weight, feed conversion efficiency, and mortality in broiler chickens. Poultry Science, 81, 815-825. https://doi.org/10.1093/ps/81.6.815

Nourmohammadi, R., \& Afzali, N. (2013). Effect of citric acid and microbial phytase on small intestinal 
morphology in broiler chicken. Italian Journal of Animal Science, 12(1), e7.

https://doi.org/10.4081/ijas.2013.e7

Nourmohammadi, R., Hosseini, S. M., Farhangfar, H., \& Bashtani, M. (2012). Effect of citric acid and microbial phytase enzyme on ileal digestibility of some nutrients in broiler chicks fed corn-soybean meal diets. Italian Journal of Animal Science, 11(1), e7. https://doi.org/10.4081/ijas.2012.e7

NRC. (2012). Nutrient Requirements of Swine. (11th revised ed.), NRC 2012 Models for estimating nutrient requirements of pigs case studies. Natl. Acad. Press, Washington, DC.

Omogbenigun, F. O., Nyachoti, C. M., \& Slominski, B. A. (2003). The effect of supplementing microbial phytase and organic acids to a corn-soybean based diet fed to early-weaned pigs. Journal of Animal Science, 81(7), 1806-1813. https://doi.org/10.2527/2003.8171806x

Patience, J. F., Bedford, M. R., Classen, H. L., \& Inborr, J. (1992). The effect of dietary enzyme supplementation of rye- and barley-based diets on digestion and subsequent performance in pigs. Canadian Journal of Animal Science, 72, 97-105. https://doi.org/10.4141/cjas92-011

Ptak, A., Jójefiak, D., Kierończyk, B., Rawski, M., Zyła, K., \& Świątkiewicz, S. (2013). Effect of different phytases on the performance, nutrient retention and tibia composition in broiler chickens. Archives of Animal Breeding, 56, 1028-1038. https://doi.org/10.7482/0003-9438-56-104

Ravindran, V., Selle, P. H., Ravindran, G., Morel, P. C. H., Kies, A. K., \& Bryden, W. L. (2001). Microbial phytase improves performance, apparent metabolizable energy, and ileal amino acid digestibility of broilers fed a lysine-deficient diet. Poultry Science, 80, 338-344. Retrieved from https://academic.oup.com/ps/article-abstract/80/3/338/1501743

Sajjadi, M., \& Carter, C. G. (2004). Dietary phytase supplementation and the utilisation of phosphorus by Atlantic salmon (Salmo salar L.) fed a canola-meal-based diet. Aquaculture, 240, 417-431. https://doi.org/10.1016/j.aquaculture.2004.07.003

Sands, J. S., Ragland, D., Dilger, R. N., \& Adeola, O. (2009). Responses of pigs to Aspergillus niger phytase supplementation of low-protein or high-phytin diets. Journal of Animal Science, 87, 2581-2589. https://doi.org/10.2527/jas.2009-1772

SAS. (2016). User's Guide: Statistics (9th ed.), SAS Inst., Inc., Cary, NC.

Sauvant, D., Perez, J. M., \& Tran, G. (2004). Tables of composition and nutritional value of feed materials: pigs, poultry, cattle, sheep, goats, rabbits, horses, fish. Wageningen Academic Publishers (Wageningen and INRA Eds.), Versailles. pp. 301. https://doi.org/10.3920/978-90-8686-668-7

Saxton, A. M. (1998). A macro for converting mean separation output to letter groupings in Proc. Mixed. Proceedings of 23rd SAS Users Group Int., Cary, NC. pp. 1243-1246.

Schlemmer, U., Jany, K. D., Berk, A., Schulz, E., \& Rechkemmer, G. (2001). Degradation of phytate in the gut of pigs-pathway of gastrointestinal inositol phosphate hydrolysis and enzymes involved. Archives of Animal Nutrition, 55(4), 255-280. https://doi.org/10.1080/17450390109386197

Seynaeve, M., Janssen, G., Hesta, M., van Nevel, C., \& Wilde, R. O. (2000a). Effects of dietary Ca/P ratio, P level and microbial phytase supplementation on nutrient digestibilities in growing pigs: precaecal, post-ileal and total tract disappearances of OM, P and Ca. Journal of Animal Physiology and Animal Nutrition, 83, 36-48. https://doi.org/10.1046/j.1439-0396.2000.00246.x

Seynaeve, M., Janssen, G., Hesta, M., van Nevel, C., \& Wilde, R. O. (2000b). Effects of dietary Ca/P ratio, P level and microbial phytase supplementation on nutrient digestibilities in growing pigs: breakdown of phytic acid, partition of $\mathrm{P}$ and phytase activity along the intestinal tract. Journal of Animal Physiology and Animal Nutrition, 83,193-204. https://doi.org/10.1046/j.1439-0396.2000.00262.x

Slominski, B. A., Jia, W., Rogiewicz, A., Nyachoti, C. M., \& Hickling, D. (2012). Low fiber canola. Part 1. Chemical and nutritive composition of the meal. Journal of Agricultural and Food Chemistry, 60, 12225-12230. https://doi.org/10.1021/jf302117x

Światkiewicz, S., Koreleski, J., \& Arczewska, A. (2010). Effect of organic acids and prebiotics on bone quality in laying hens fed diets with two levels of calcium and phosphorus. Acta Vet. Brno, 79, 185-193. https://doi.org/10.2754/avb201079020185

Thacker, P. A. (2001). Effect of enzyme supplementation on the performance of growing-finishing pigs fed barley-based diets supplemented with soybean meal or canola meal. Asian-Australian Journal of Animal 
Science, 14, 1008-1013. https://doi.org/10.5713/ajas.2001.1008

Thacker, P. A., \& Newkirk, R. W. (2005). Performance of growing-finishing pigs fed barley-based diets containing toasted or non-toasted canola meal. Canadian Journal of Animal Science, 85(1), 53-59. https://doi.org/10.4141/A04-056

Van Kleef, D. J., Deuring, K., \& Van Leeuwen, P. (1994). A new method of faeces collection in the pig. Laboratory Animals, 28(1), 78-79. https://doi.org/10.1258/002367794781065942

Wilcock, P. (2012). Superdosing phytase post weaning to improve pig performance. International Pig Topics, 27(5), 21-23. Retrieved from http://www.positiveaction.co.uk

Yin, Y.-L., Baidoo, S. K., Jin, L. Z., Liu, Y. G., Schulze, H., \& Simmins, P. H. (2001). The effect of different carbohydrase and protease supplementation on apparent (ileal and overall) digestibility of nutrients of five hulless barley varieties in young pigs. Livestock Production Science, 71, 109-120.

https://doi.org/10.1016/S0301-6226(01)00215-9

\section{Copyrights}

Copyright for this article is retained by the author(s), with first publication rights granted to the journal.

This is an open-access article distributed under the terms and conditions of the Creative Commons Attribution license (http://creativecommons.org/licenses/by/3.0/). 